Research Paper

\title{
Cooperation of Doxycycline with Phytochemicals and Micronutrients Against Active and Persistent Forms of Borrelia sp
}

\author{
Anna Goc ${ }^{\bowtie}$, Alexandra Niedzwiecki ${ }^{\bowtie}$, Matthias Rath \\ Dr. Rath Research Institute BV, Santa Clara, California 95050, USA. \\ $\triangle$ Corresponding authors: 1) Alexandra Niedzwiecki, e-mail: a.niedz@drrath.com. Dr. Rath Research Institute BV, 1260 Memorex Dr., Santa Clara, 95050 CA. \\ Tel. 408-567-5050, Fax: 408-748-1726. 2) Anna Goc, e-mail: a.goc@drrath.com. Dr. Rath Research Institute BV, 1260 Memorex Dr., Santa Clara, 95050 CA. Tel. \\ 408-588-7108, Fax: 408-748-1726. \\ (C) Ivyspring International Publisher. Reproduction is permitted for personal, noncommercial use, provided that the article is in whole, unmodified, and properly cited. See \\ http://ivyspring.com/terms for terms and conditions.
}

Received: 2016.05.04; Accepted: 2016.07.14; Published: 2016.07.22

\begin{abstract}
Phytochemicals and micronutrients represent a growing theme in antimicrobial defense; however, little is known about their anti-borreliae effects of reciprocal cooperation with antibiotics. A better understanding of this aspect could advance our knowledge and help improve the efficacy of current approaches towards Borrelia sp. In this study, phytochemicals and micronutrients such as baicalein, luteolin, 10-HAD, iodine, rosmarinic acid, and monolaurin, as well as, vitamins D3 and C were tested in a combinations with doxycycline for their in vitro effectiveness against vegetative (spirochetes) and latent (rounded bodies, biofilm) forms of Borrelia burgdorferi and Borrelia garinii. Anti-borreliae effects were evaluated according to checkerboard assays and supported by statistical analysis. The results showed that combination of doxycycline with flavones such as baicalein and luteolin exhibited additive effects against all morphological forms of studied Borrelia $s p$. Doxycycline combined with iodine demonstrated additive effects against spirochetes and biofilm, whereas with fatty acids such as monolaurin and 10-HAD it produced FICls of indifference. Additive anti-spirochetal effects were also observed when doxycycline was used with rosmarinic acid and both vitamins D3 and C. Antagonism was not observed in any of the cases. This data revealed the intrinsic anti-borreliae activity of doxycycline with tested phytochemicals and micronutrients indicating that their addition may enhance efficacy of this antibiotic in combating Borrelia sp. Especially the addition of flavones balcalein and luteolin to a doxycycline regimen could be explored further in defining more effective treatments against these bacteria.
\end{abstract}

Key words: Borrelia sp., spirochetes, cysts, biofilm, phytochemicals, doxycycline.

\section{Introduction}

Bacteria from genus Borrelia are mico-aerophilic and slow-growing pathogens known for their persistency [1-7]. Out of 36 currently recognized species, 13 of them are either acknowledged or suspected to cause Lyme disease (LD) which is the most common tick-born infection in Europe and North America [8-11]. They are known as Borrelia burgdorferi sensu lato and include species such as Borrelia burgdroferi sensu stricto (predominantly causing this illness in North America) as well as Borrelia afzelii and Borrelia garinii (predominantly causing this illness in Europe) [12]. The vegetative form of Borrelia sp. are spirochetes that are motile and can survive viscous conditions in human and animal blood, and as well they are capable of entering their cells [13-16]. When hostile conditions are introduced these bacteria can adopt different latent forms such as rounded bodies (cysts, granular forms, L-forms) and 
aggregates (biofilm-like structures) [17-19]. Especially the ability of Borrelia burgdorferi sensu lato to convert and re-convert to cystic form was observed, which may be one of the reasons why this infection can sometimes become persistent and/or re-surface after being silent for a long time. [19-21]. Moreover, genomic analysis revealed that Borrelia burgdorferi sensu lato has a gene for efflux mechanism. This might be responsible for developing antibiotic resistance, although more in depth studies are warranted to prove such hypothesis [22]. These aspects all highlight the need for either new or improved treatments against Borrelia sp. [21].

Based on diagnostic test results, the most recent estimates, indicate that the number of LD cases in just the United States reaches 300,000 each year; however, there might be unreported cases that are not reflected in the statistics $[10,19,23,24]$. This has made this disease the most common vector-born disease in the Northern Hemisphere [10-11, 19]. Currently, the frontline treatment for LD is based on antibiotics. Beta lactams are the most frequently applied and include doxycycline, amoxicillin, and cefuroxime axetil. Macrolides, such as azithromycin, clarithromycin, and erythromycin, are the second class and appear to be less effective than beta lactams [25].

Currently one of the most often prescribed antibiotics against Borrelia burgdorferi sensu lato infection is doxycycline [25-29]. Its use began in the late sixties last century against infections other than $\operatorname{LD}[30,31]$. Since then, the application of doxycycline extended and has been on the World Health Organization's List of Essential Medicines as one of the most important medications needed in a basic health system [31, 32]. Doxycycline is a broad-spectrum antibiotic belonging to the class of tetracyclines. Like other agents in this class, it is an anti-bacterial and anti-parasite agent targeting protein production in general [31-33]. Its side effects are similar to those of other members of this antibiotic class, including the development of an erythematous rash after exposure to sun. Moreover, doxycycline is classified as a class D drug and is thus restricted for administration to pregnant women and children under the age of eight [34]. Although, doxycycline is one of the most frequently prescribed antibiotics, especially for the early stages of LD, its continued treatment is not recommended since the long-term effectiveness has not been proven [4, 35]. In vitro studies revealed that doxycycline is very effective against active (vegetative) form of Borrelia $s p$. ., with moderate action against their biofilms, and ineffective against the latent rounded forms [2, 36]. Observed persistency and/or relapse of LD symptoms in the absence of ongoing antibiotic treatment was observed as well [19, 21, 37]. This would suggest that doxycycline may either facilitate generation of latent forms or is inefficient in their elimination $[5,17$, 38-40]. While, it was shown that doxycycline has no useful activity against latent rounded forms of Borrelia $s p$., its general activity could potentially be improved if applied in combination with other antimicrobial agents that express similar or complementary action.

Antimicrobials derived from natural sources such as plants, herbs, and fruits, and essential oils, have shown activity against a plethora of bacteria and fungi, but are poorly explored against Borrelia $s p$. [41-43]. Despite a rather small pool of available data on this subject, Bronson and Bronson study exhibited grapefruit seed extract as a powerful in vitro agent against spirochetes and their cystic forms of Borrelia afzelii [44]. Dipsacus sylvestris extract against Borrelia burgdorferi sensu stricto revealed growth inhibiting activity as well [45], whereas Sapi, et al., reported significant efficacy of leaf extracts from Stevia rebaudiana on all forms of Borrelia burgdorferi sensu stricto [46]. Our recent study documented that other naturally occurring compounds like baicalein and luteolin, belonging to the flavones, are also potent against Borrelia sp. In addition, fatty acids, including monolaurin and cis-2-decenoic acid, and iodine exhibited significant bacteriostatic and bactericidal activities [47]. Our and other studies indicate that naturally derived compounds and antibiotics that display essential anti-borreliae activities might be an option for achieving optimal bacteriostatic and bactericidal activity at lower MICs and MBCs, which could potentially reduce their side effects and treatment costs.

In this study, we examined reciprocal cooperation of selected phytochemicals and micronutrients with documented anti-borrelae activities, with commercial antibiotic doxycycline against two Borrelia species. To our knowledge, this is the first scientific report about interaction between doxycycline and phytochemicals and micronutrients against active and latent forms of Borrelia sp.

\section{Materials and Methods}

Test compounds. The compounds such as baicalein, vitamin D3, vitamin $\mathrm{C}$, cis-2-decenoic acid (10-HAD) and doxycycline, with the purity between $90 \%-98 \%$ according to the manufacturer, were obtained from Sigma (St. Louis, MO). Luteolin and rosmarinic acid, with the purity between 97\%-99\% according to the manufacturer, were purchased from Tocris Bioscience (Bristol, United Kingdom). Kelp with standardized iodine content (i.e., $150 \mu \mathrm{g} / \mathrm{ml}$ as $100 \%$ of Daily Value) was from World Organic Ltd. (Auckland, New Zealand). Monolaurin (Lauricidin ${ }^{\circledR}$ ), 
as a pure sn- 1 monolaurin (glycerol monolaurate) derived from coconut oil, was from Med-Chem Laboratories, Inc., (Goodyear, AZ).

Preparation of test compounds for susceptibility testing. A stock solution (50-100 $\mathrm{mg} / \mathrm{ml}$ ) of each compound (depending on solubility of the substance) was prepared by suspending individual test compounds in absolute ethanol and sterilized by $0.22 \mu \mathrm{m}$ syringe filtration. All stock solutions were stored in aluminum foil-wrapped tubes at $-20^{\circ} \mathrm{C}$. Due to bactericidal effect of a high percentage of ethanol, its added amount to the growth medium was kept below $0.4 \%(\mathrm{v} / \mathrm{v})$. A preliminary experiment determined that ethanol content should not exceed $0.5 \% \quad(\mathrm{v} / \mathrm{v})$ (data not shown). The appropriate amount of each stock solution was then added to $1.8 \mathrm{ml}$ sterile screw-cap test tubes containing $1 \mathrm{ml}$ of BSK-H complete medium to yield final concentrations of $5-500 \mu \mathrm{g} / \mathrm{ml}$ for all compounds. As a negative control, ethanol at $0.1-0.4 \%(\mathrm{v} / \mathrm{v})$ was applied.

Test microorganisms. Two Borrelia species such as Borrelia burgdorferi sensu stricto and Borrelia garinii were tested in their three morphological forms: spirochetes, rounded forms, and biofilm. Low passage isolates of the B31 strain of Borrelia burgdorferi and CIP103362 strain of Borrelia garinii were obtained from the American Type Culture Collection (Manassas, VA). B31 strain is an isolate from Ixodes dammini whereas the CIP103362 strain is an isolate from Ixodes ricinus. The stocks of both species were cultured in commonly used conditions, i.e., Barbour-Stoner-Kelly $\mathrm{H}$ (BSK-H) medium supplemented with 6\% rabbit serum (Sigma, St. Louis, MO) without antibiotics at $33^{\circ} \mathrm{C}$ in $5 \% \mathrm{CO}_{2}$, in sterile screw-cap $15 \mathrm{ml}$ polypropylene test tubes with or without gentle shaking.

Preparation of test microorganisms for susceptibility testing. Both examined strains of Borrelia sp. were prepared for testing according to Sapi, et al. [2]. Briefly, the strains were activated from original cryobank vials and inoculated into $10 \mathrm{ml}$ BSK-H complete medium, and maintained at $33^{\circ} \mathrm{C}$ in $5 \% \mathrm{CO}_{2}$. Generation of homogeneous cultures (i.e., having only spirochete form) of tested Borrelia $s p$. were obtained by maintaining the inoculums in a shaking incubator at $33^{\circ} \mathrm{C}$ and $250 \mathrm{rpm}$ where there is no biofilm formation, respectively [2]. Generation of biofilm-like colonies of tested Borrelia sp. was attained by incubation of inoculums in 4-well chambers (BD Biosciences, Sparks, MD) coated with collagen type I from rat tail for up to one week without shaking at $33^{\circ} \mathrm{C}$ in $5 \% \mathrm{CO}_{2}$, respectively.

Evaluation of the reciprocal activities of test compounds on test microorganisms. Interaction of doxycycline with studied phytochemicals was assessed against spirochetes and rounded forms in 1.8 $\mathrm{ml}$ sterile screw-capped test tubes as well as against biofilm in 4-well chambers coated with collagen I from rat tail, according to checkerboard format. Samples were inoculated with inoculums of test organisms, respectively, and set up at the appropriate times with increasing concentrations of doxycycline (DOX) $(0$ to $500 \mu \mathrm{g} / \mathrm{ml})$ and the active phytochemical (PH) $(0$ to $500 \mu \mathrm{g} / \mathrm{ml}$ ) or micronutrient (0 to 88 $\mu \mathrm{g} / \mathrm{ml})$, according to checkerboard assay. These ranges were selected based on our earlier studies and other research groups (applied as a single dose, not in combination with a partner agent) [2,47]. All tubes and chambers with mature biofilm were then incubated at $33^{\circ} \mathrm{C}$ for up to $72 \mathrm{~h}$ in $5 \% \mathrm{CO}_{2}$. Each tube was subjected to microscopic evaluation and chambers to spectrometric evaluations. Fractional inhibitory concentration indexes (FICIs), fractional bactericidal concentration indexes (FBCIs), and fractional eradication (of biofilm) concentration indexes (FECIs) were calculated and interpreted as follows: synergy $=\mathrm{FICI} / \mathrm{FBCI} / \mathrm{FECI}$ of $\leq 0.5$; antagonism $=\mathrm{FICI} / \mathrm{FBCI} / \mathrm{FECI}>4.0$; additive $=0.5<$ $\mathrm{FICI} / \mathrm{FBCI} / \mathrm{FECI}<1.0$, and indifferent (no interaction) $=1.0<\mathrm{FICI} / \mathrm{FBCI} / \mathrm{FECI}<4.0$ [48-50]. Discrepant results with FICI/FBCI/FECI $\leq 1$ were confirmed by performing an additional duplicate test.

Evaluation of reciprocal activities of tested combinations of agents against spirochetes of Borrelia sp. Reciprocity of test compounds against spirochetes of studied Borrelia sp. was performed using a macro-dilution method according to checkerboard format. Briefly, $1.8 \mathrm{ml}$ sterile screw-capped test tubes containing $1 \mathrm{ml}$ BSK-H complete medium, supplemented with the tested combinations of agents were inoculated with $2 \times 10^{6}$ spirochetes $/ \mathrm{ml}$ of the homogenous bacterial suspension. The tubes were then incubated at $33^{\circ} \mathrm{C}$ in $5 \% \mathrm{CO}_{2}$ and growth and viability was monitored at regular intervals for up to $72 \mathrm{~h}$ using a bacterial Petroff-Hausser counting chamber with dark field microscopy and/or LIVE/DEAD ${ }^{\circledR}$ BacLight $^{\mathrm{TM}}$ Bacterial Viability staining with fluorescent microscopy as a standard procedure. Control cultures were treated with ethanol (i.e., 0.1-0.4 v/v) alone. FICIs were calculated as follows: $\mathrm{FIC}_{\mathrm{DOX}}=$ $\mathrm{MIC}_{\mathrm{DOX}+\mathrm{PH}} / \mathrm{MIC}_{\mathrm{DOX}}+\mathrm{FIC}_{\mathrm{PH}}=\mathrm{MIC} \mathrm{PH}_{\mathrm{DOX}} / \mathrm{MIC}_{\mathrm{PH}}$. FBCIs were calculated as follows: $\mathrm{FBC}_{\mathrm{DOX}}=$ $\mathrm{MBC}_{90 \mathrm{DOX}+\mathrm{PH}} / \mathrm{MBC}_{90 \mathrm{DOX}}+\mathrm{FBC}_{\mathrm{PH}}=\mathrm{MBC}_{90 \mathrm{PH}+\mathrm{DOX}} /$ $\mathrm{MBC}_{90 \mathrm{PH}}$, as standard calculations [50-52]. The experiment was repeated three times for each species and each tested compounds combination.

Evaluation of reciprocal activities of tested combinations of agents against rounded forms of 
Borrelia sp. Efficacy of test compound combinations against rounded forms was examined using a LIVE/DEAD ${ }^{\circledR}$ BacLight $^{\mathrm{TM}}$ Bacterial Viability staining method, where green fluorescence determines the presence of live rounded forms and red fluorescence dead rounded forms, using a macro-dilution method according to checkerboard format. Briefly, $2 \times 10^{6}$ spirochetes $/ \mathrm{ml}$ of the homogenous bacterial suspension was inoculated into each $1.8 \mathrm{ml}$ sterile screw-capped test tubes containing $1 \mathrm{ml}$ BSK-H complete medium, supplemented with the tested combinations of agents. The tubes were then incubated at $33^{\circ} \mathrm{C}$ in $5 \% \mathrm{CO}_{2}$ and viability was monitored at regular intervals for up to $72 \mathrm{~h}$ using fluorescent microscopy (Nikon, Eclipse E600) as standard procedure. Control cultures were treated with ethanol (0.1-0.4 v/v) alone. FBCIs were calculated as follows: $\mathrm{FBC}_{\mathrm{DOX}}=\mathrm{MBC}_{50 \mathrm{DOX}+\mathrm{PH}} /$ $\mathrm{MBC}_{50 \mathrm{DOX}}+\mathrm{FBC}_{\mathrm{PH}}=\mathrm{MBC}_{50 \mathrm{PH}+\mathrm{DOX}} / \mathrm{MBC}_{50 \mathrm{PH}}$, where $\mathrm{MBC}_{50}$ is a minimal concentration causing $50 \%$ of killing. The experiment was repeated three times for each species and each tested compounds combination.

Evaluation of reciprocal activities of tested combinations of agents against biofilms of Borrelia $s p$. Efficacy of test compound combinations against biofilm of tested Borrelia sp. was evaluated using the qualitative method based on crystal violet staining [2]. Briefly, $1 \times 10^{7}$ spirochetes $/ \mathrm{ml}$ of the homogeneous culture were inoculated into four-well chambers coated with collagen type I and incubated at $33^{\circ} \mathrm{C}$ in $5 \% \mathrm{CO}_{2}$ for up to one week. Earlier studies in our laboratory have documented a lack of antifungal carryover using this procedure [47]. Once the biofilm was established, all chambers were supplemented with the tested combinations of agents and incubated at $33^{\circ} \mathrm{C}$ in $5 \% \mathrm{CO}_{2}$ for up to $72 \mathrm{~h}$. Control wells were treated with ethanol $(0.1-0.4 \mathrm{v} / \mathrm{v})$ alone. All wells were fixed with $500 \mu \mathrm{l}$ of cold methanol-formalin (1:1) for 30 minutes and stained with $1 \mathrm{ml}$ of crystal violet $(0.1 \%)$ for 10 minutes. The biofilms were then washed carefully three times with $1 \times$ PBS (phosphate-buffered saline), and $1 \mathrm{ml}$ of methanol was added to each well to extract a dye which was measured at $595 \mathrm{~nm}$ using a spectrophotometer (Molecular Device, Spectra Max 340). Reciprocal interaction was evaluated according to checkerboard format and the percentage of biofilm eradication $(\mathrm{BE} \%)$ was calculated as $\mathrm{BE} \%=\left[1-\left(\mathrm{OD}_{959}\right.\right.$ of cells treated with Doxycycline and Phytochemical (micronutrient)/OD 959 of untreated control] x 100\%. Also, fractional eradication concentration indexes FECIs (adapted from the FICI/FBCI equation reported by Elion, et al.) were calculated as follows: $\mathrm{FEC}_{\mathrm{DOX}}=\mathrm{EC}_{50 \mathrm{DOX}+\mathrm{PH}} / \mathrm{EC}_{50 \mathrm{DOX}}+\mathrm{FEC}_{\mathrm{PH}}=$ $\mathrm{EC}_{50 \mathrm{PH}+\mathrm{DOX}} / \mathrm{EC}_{50 \mathrm{PH}}$, where $\mathrm{EC}_{50}$ is an effective concentration causing at least $50 \%$ of biofilm eradication [53]. The experiment was repeated three times for each species and each compounds combination. For quantitative analysis, all chambers were fixed with $500 \mu \mathrm{l}$ of cold formalin-acetic acid mixture for $20 \mathrm{~min}$. followed by staining with $200 \mu \mathrm{l}$ of BacLight staining mixture for $15 \mathrm{~min}$. in the dark, according to the manufacturer's recommendation. Pictures were immediately taken from untreated (control) and treated mounted slides using a fluorescence microscope (Nikon, Eclipse E600).

2.9. Statistical analysis. All data are presented as means \pm SD $(n=3)$. The ANOVA and/or Student's two-tailed $t$ test was used to determine statistically significant differences set at 0.05 levels. Statistical analysis was performed using GraphPad software.

\section{Results}

Reciprocal cooperation between doxycycline and tested phytochemicals against spirochetes of Borrelia sp. The examined combinations of doxycycline with tested phytochemicals and micronutrients against spirochetes of test microorganisms with the MICs, FICs and FICIs values are presented in Table $1 \mathrm{~A}$. The $\mathrm{MBC}_{90} \mathrm{~S}, \mathrm{FBCs}$ and FBCIs values are presented in Table 1B. Screening of tested combinations indicates additive effects $(0.5<$ FICI < 1.0) of doxycycline with 6 partner agents such as baicalein, luteolin, iodine, rosmarinic acid, vitamin D3, and vitamin C. Indifference (no interaction) was seen between doxycycline and fatty acids like monolaurin and 10-HAD. No antagonistic interaction was noticed in any of the combinations. Adding phytochemicals and micronutrients allowed for lowering of doxycycline MIC value from $25 \mu \mathrm{g} / \mathrm{ml}$ to $12.5 \mu \mathrm{g} / \mathrm{ml}$ (valid for both tested Borrelia sp.). Adding phytochemicals and micronutrients allowed for lowering of doxycycline $\mathrm{MBC}_{90}$ value from $200 \mu \mathrm{g} / \mathrm{ml}$ to $100 \mu \mathrm{g} / \mathrm{ml}$ (for B. burgdorferi) and from $250 \mu \mathrm{g} / \mathrm{ml}$ to $125 \mu \mathrm{g} / \mathrm{ml}$ (for B. garinii). The presence of sub-inhibitory concentration of doxycycline (12.5 $\mu \mathrm{g} / \mathrm{ml}$ ) reduced the MICs of the partner phytochemical agents that fluctuated between 62.5 $\mu \mathrm{g} / \mathrm{ml}$ and $150 \mu \mathrm{g} / \mathrm{ml}$ and the partner micronutrient agents between $0.00025 \mu \mathrm{g} / \mathrm{ml}$ and $44 \mu \mathrm{g} / \mathrm{ml}$. FICs and FICIs for all tested agent combinations corresponded to each other for both tested Borrelia $s p$. The presence of sub-bactericidal concentration of doxycycline $(100 \mu \mathrm{g} / \mathrm{ml}$ for B. burgdorferi; $125 \mu \mathrm{g} / \mathrm{ml}$ $B$. garinii) reduced the $\mathrm{MBC}_{90}$ values of the phytochemical agents that ranged between $125 \mu \mathrm{g} / \mathrm{ml}$ and $225 \mu \mathrm{g} / \mathrm{ml}$ and the partner micronutrient agents between $0.0005 \mu \mathrm{g} / \mathrm{ml}$ and $44 \mu \mathrm{g} / \mathrm{ml}$. FBCs and FBCIs for all tested agent combinations corresponded to each other for both tested Borrelia $s p$. 
Table 1A. Bacteriostatic reciprocal cooperation of doxycycline with phytochemicals and micronutrients against spirochete form of Borrelia burgdorferi and Borrelia garinii.

\begin{tabular}{|c|c|c|c|c|c|c|c|c|c|c|}
\hline \multirow[t]{3}{*}{ Tested combination } & \multicolumn{5}{|c|}{ Borrelia burgdorferi } & \multicolumn{5}{|c|}{ Borrelia garinii } \\
\hline & \multicolumn{2}{|c|}{ MIC in combination } & \multicolumn{2}{|c|}{ FIC } & \multirow[t]{2}{*}{ FICI } & \multicolumn{2}{|c|}{ MIC in combination } & \multicolumn{2}{|c|}{ FIC } & \multirow[t]{2}{*}{ FICI } \\
\hline & $\begin{array}{l}\text { PH } \\
(\mu \mathrm{g} / \mathrm{ml})\end{array}$ & $\begin{array}{l}\text { DOX } \\
(\mu \mathrm{g} / \mathrm{ml})\end{array}$ & $\mathrm{PH}$ & DOX & & $\begin{array}{l}\text { PH } \\
(\mu \mathrm{g} / \mathrm{ml})\end{array}$ & $\begin{array}{l}\text { DOX } \\
(\mu \mathrm{g} / \mathrm{ml})\end{array}$ & $\mathrm{PH}$ & DOX & \\
\hline \multicolumn{11}{|l|}{ Polyphenols } \\
\hline Baicalein+DOX & 75 & 12.5 & 0.5 & 0.5 & 1.0 & 75 & 12.5 & 0.5 & 0.5 & 1.0 \\
\hline Luteolin+DOX & 62.5 & 12.5 & 0.5 & 0.5 & 1.0 & 75 & 12.5 & 0.5 & 0.5 & 1.0 \\
\hline RA+DOX & 75 & 12.5 & 0.5 & 0.5 & 1.0 & 75 & 12.5 & 0.5 & 0.5 & 1.0 \\
\hline \multicolumn{11}{|l|}{ Fatty acids } \\
\hline Monolaurin+Dx & 70 & 12.5 & 0.7 & 0.5 & 1.2 & 70 & 12.5 & 0.7 & 0.5 & 1.2 \\
\hline 10-HAD+DOX & 125 & 12.5 & 1.0 & 0.5 & 1.5 & 150 & 12.5 & 0.6 & 0.5 & 1.1 \\
\hline \multicolumn{11}{|l|}{ Micronutrients } \\
\hline Iodine+DOX & 2.5 & 12.5 & 0.5 & 0.5 & 1.0 & 2.5 & 12.5 & 0.5 & 0.5 & 1.0 \\
\hline Vitamin D3+DOX & 0.00025 & 12.5 & 0.5 & 0.5 & 1.0 & 0.00025 & 12.5 & 0.5 & 0.5 & 1.0 \\
\hline Vitamin C+DOX & 17.5 & 12.5 & 0.5 & 0.5 & 1.0 & 44 & 12.5 & 0.5 & 0.5 & 1.0 \\
\hline
\end{tabular}

Abbreviations: MIC-minimal inhibitory concentration, FIC-fractional inhibitory concentration, FICI-fractional inhibitory concentration index, PH-phytochemical/micronutrient,

DOX-doxycycline, RA-rosmarinic acid.

MICs of single dose of: doxycycline $(25 \mu \mathrm{g} / \mathrm{ml})$, baicalein $(150 \mu \mathrm{g} / \mathrm{ml})$, luteolin $(125 \mu \mathrm{g} / \mathrm{ml}$ for B. burgdorferi, $150 \mu \mathrm{g} / \mathrm{ml}$ for B. garinii), monolaurin $(100 \mu \mathrm{g} / \mathrm{ml}), 10-\mathrm{HAD}(125 \mu \mathrm{g} / \mathrm{ml}$ for $B$.

burgdorferi, $250 \mu \mathrm{g} / \mathrm{ml}$ for B. garinii), rosmarinic acid $(150 \mu \mathrm{g} / \mathrm{ml})$, iodine $(5 \mu \mathrm{g} / \mathrm{ml})$, vitamin D3 $(0.0005 \mu \mathrm{g} / \mathrm{ml})$, vitamin C ( $35 \mu \mathrm{g} / \mathrm{ml}$ for B. burgdorferi, $88 \mu \mathrm{g} / \mathrm{ml}$ for B. garinii) [47].

Table 1B. Bactericidal reciprocal cooperation of doxycycline with phytochemicals and micronutrients against spirochete form of Borrelia burgdorferi and Borrelia garinii.

\begin{tabular}{|c|c|c|c|c|c|c|c|c|c|c|}
\hline \multirow[t]{3}{*}{ Tested combination } & \multicolumn{5}{|c|}{ Borrelia burgdorferi } & \multicolumn{5}{|c|}{ Borrelia garinii } \\
\hline & \multicolumn{2}{|c|}{$\mathrm{MBC}_{90}$ in combination } & \multicolumn{2}{|c|}{ FBC } & \multirow[t]{2}{*}{ FBCI } & \multicolumn{2}{|c|}{$\mathrm{MBC}_{90}$ in combination } & \multicolumn{2}{|c|}{ FBC } & \multirow[t]{2}{*}{ FBCI } \\
\hline & $\begin{array}{l}\text { PH } \\
(\mu \mathrm{g} / \mathrm{ml})\end{array}$ & $\begin{array}{l}\text { DOX } \\
(\mu \mathrm{g} / \mathrm{ml})\end{array}$ & $\mathrm{PH}$ & DOX & & $\begin{array}{l}\text { PH } \\
(\mu \mathrm{g} / \mathrm{ml})\end{array}$ & $\begin{array}{l}\text { DOX } \\
(\mu \mathrm{g} / \mathrm{ml})\end{array}$ & $\mathrm{PH}$ & DOX & \\
\hline \multicolumn{11}{|l|}{ Polyphenols } \\
\hline Baicalein+DOX & 125 & 100 & 0.5 & 0.5 & 1.0 & 125 & 125 & 0.5 & 0.5 & 1.0 \\
\hline Luteolin+DOX & 125 & 100 & 0.5 & 0.5 & 1.0 & 125 & 125 & 0.5 & 0.5 & 1.0 \\
\hline RA+DOX & 125 & 100 & 0.5 & 0.5 & 1.0 & 125 & 125 & 0.5 & 0.5 & 1.0 \\
\hline \multicolumn{11}{|l|}{ Fatty acids } \\
\hline Monolaurin+Dx & 200 & 100 & 0.8 & 0.5 & 1.3 & 200 & 125 & 0.8 & 0.5 & 1.3 \\
\hline 10-HAD+DOX & 225 & 100 & 0.9 & 0.5 & 1.4 & 225 & 125 & 0.9 & 0.5 & 1.4 \\
\hline \multicolumn{11}{|l|}{ Micronutrients } \\
\hline Iodine+DOX & 7.5 & 100 & 0.5 & 0.5 & 1.0 & 7.5 & 125 & 0.5 & 0.5 & 1.0 \\
\hline Vitamin D3+DOX & 0.0005 & 100 & 0.5 & 0.5 & 1.0 & 0.0005 & 125 & 0.5 & 0.5 & 1.0 \\
\hline Vitamin C+DOX & 44 & 100 & 0.5 & 0.5 & 1.0 & 44 & 125 & 0.5 & 0.5 & 1.0 \\
\hline
\end{tabular}

Abbreviations: $\mathrm{MBC} 90-$ minimal bactericidal concentration causing at least $90 \%$ of killing, FBC-fractional bactericidal concentration, $\mathrm{FBCI}$-fractional bactericidal concentration index, $\mathrm{PH}$-phytochemical/micronutrient, DOX-doxycycline, RA-rosmarinic acid.

MBCs of single dose of: doxycycline $(200 \mu \mathrm{g} / \mathrm{ml}$ for B. burgdorferi, $250 \mu \mathrm{g} / \mathrm{ml}$ for B. garinii), baicalein $(250 \mu \mathrm{g} / \mathrm{ml})$, luteolin $(250 \mu \mathrm{g} / \mathrm{ml}), \mathrm{monolaurin}(250 \mu \mathrm{g} / \mathrm{ml}), 10-\mathrm{HAD}(250 \mu \mathrm{g} / \mathrm{ml})$, rosmarinic acid $(250 \mu \mathrm{g} / \mathrm{ml})$, iodine $(15 \mu \mathrm{g} / \mathrm{ml})$, vitamin D3 $(0.001 \mu \mathrm{g} / \mathrm{ml})$, vitamin C $(88 \mu \mathrm{g} / \mathrm{ml})[47]$

Reciprocal cooperation between doxycycline and tested phytochemicals against rounded forms of Borrelia sp. The effects of doxycycline in combination with tested phytochemicals and micronutrients against rounded forms of both studied Borrelia sp. are presented in Table 2, with their $\mathrm{MBC}_{50} \mathrm{~S}$, FBCs and FBCIs. Our previous results indicated that among several tested compounds, a few (baicalein, luteolin, monolaurin, 10-HAD, and iodine) showed anti-rounded forms efficacy that satisfied the $\mathrm{MBC}_{50}$ requirement. The other agents (rosmarinic acid, vitamin D3, vitamin C, and doxycycline) did not affect rounded forms to this extent [47]. Evaluation of all the phytochemicals and micronutrients in combination with doxycycline did not indicate synergy or antagonistic interaction in any of the cases. However, we noticed an additive effect which was restricted to combinations of doxycycline with baicalein or its close related agent luteolin, in both studied Borrelia $s p$.
Their FBCs and FBCIs corresponded to each other for both tested species of Borrelia. Combinations of doxycycline with flavones were able to induce the death of latent rounded forms up to $50 \%$ at lower concentrations of each partner agent. As such, effective concentrations of baicalein decreased from $350 \mu \mathrm{g} / \mathrm{ml}$ to $275 \mu \mathrm{g} / \mathrm{ml}$, luteolin decreased from 200 $\mu \mathrm{g} / \mathrm{ml}$ to $150 \mu \mathrm{g} / \mathrm{ml}$, and doxycycline decreased from $500 \mu \mathrm{g} / \mathrm{ml}$ to $100 \mu \mathrm{g} / \mathrm{ml}$. Indifference (no interaction) was seen between doxycycline and fatty acids such as monolaurin and $10-\mathrm{HAD}$ as well as iodine. $\mathrm{MBC}_{50}$ mark was achieved at their values identical to their single dose such as $300 \mu \mathrm{g} / \mathrm{ml}$ for monolaurin, 500 $\mu \mathrm{g} / \mathrm{ml}$ for $10-\mathrm{HAD}$ and $20 \mu \mathrm{g} / \mathrm{ml}$ for iodine. However, at the same time, their addition allowed for reducing effective doxycycline concentration from 500 $\mu \mathrm{g} / \mathrm{ml}$ to $100 \mu \mathrm{g} / \mathrm{ml}$. The combinations with the rest of the tested agents did not achieve $\mathrm{MBC}_{50}$ mark, which did not allow performing correct calculations. 
None of the added tested agents alone or in combinations could eliminate rounded forms in $90-99 \%$, even at their maximal tested concentrations. This is a very rigorous requirement for many antibiotics, including doxycycline. Its efficacy was shown to be $\sim 5-10 \%$ at $500 \mu \mathrm{g} / \mathrm{ml}[2,47,54]$.

Kinetic evaluation of bactericidal effect against spirochetes and rounded forms of Borrelia $s p$. Kinetic evaluation of bactericidal effect of baicalein and luteolin was conducted as these compounds were able to eliminate both spirochete and rounded forms of tested Borrelia $s p$. The results of this experiment show that doxycycline in combination with these phytochemicals, used at concentrations fulfilling the $0.5<\mathrm{FBCI}<1.0$ requirement, could significantly eliminate spirochetes of Borrelia burgdorferi and Borrelia garinii in a dose- and time-dependent manner, reaching $\mathrm{MIC}_{50}$ mark after $24 \mathrm{~h}$ and $\mathrm{MIC}_{90}$ mark after $72 \mathrm{~h}$ (Figure 1A and B). Similarly, dose-and time-dependent killing effect on their rounded forms was noticed with $M C_{50}$ mark reached after $72 \mathrm{~h}$ (Figure 2A-C) at concentrations fulfilling the $0.5<$ $\mathrm{FBCI}<1.0$ requirement.

Table 2. Antibacterial reciprocal cooperation of doxycycline with phytochemicals and micronutrients against rounded forms of Borrelia burgdorferi and Borrelia garinii.

\begin{tabular}{|c|c|c|c|c|c|c|c|c|c|c|}
\hline \multirow[t]{3}{*}{ Tested combination } & \multicolumn{5}{|c|}{ Borrelia burgdorferi } & \multicolumn{5}{|c|}{ Borrelia garinii } \\
\hline & \multicolumn{2}{|c|}{$\mathrm{MBC}_{50}$ in combination } & \multicolumn{2}{|c|}{ FBC } & \multirow[t]{2}{*}{ FBCI } & \multicolumn{2}{|c|}{$\mathrm{MBC}_{50}$ in combination } & \multicolumn{2}{|c|}{ FBC } & \multirow[t]{2}{*}{ FBCI } \\
\hline & $\begin{array}{l}\text { PH } \\
(\mu \mathrm{g} / \mathrm{ml})\end{array}$ & $\begin{array}{l}\text { DOX } \\
(\mu \mathrm{g} / \mathrm{ml})\end{array}$ & PH & DOX & & $\begin{array}{l}\mathrm{PH} \\
(\mu \mathrm{g} / \mathrm{ml})\end{array}$ & $\begin{array}{l}\text { DOX } \\
(\mu \mathrm{g} / \mathrm{ml})\end{array}$ & $\mathrm{PH}$ & DOX & \\
\hline \multicolumn{11}{|l|}{ Polyphenols } \\
\hline Baicalein+DOX & 275 & 100 & 0.79 & 0.2 & 0.99 & 275 & 100 & 0.79 & 0.2 & 0.99 \\
\hline Luteolin+DOX & 150 & 100 & 0.75 & 0.2 & 0.95 & 150 & 100 & 0.75 & 0.2 & 0.95 \\
\hline RA+DOX & $500^{*}$ & $500^{*}$ & NS & NS & NA & $500^{*}$ & $500^{*}$ & NS & NS & NA \\
\hline \multicolumn{11}{|l|}{ Fatty acids } \\
\hline Monolaurin+Dx & 300 & 100 & 1.0 & 0.2 & 1.2 & 300 & 100 & 1.0 & 0.2 & 1.2 \\
\hline 10-HAD+DOX & 500 & 100 & 1.0 & 0.2 & 1.2 & 500 & 100 & 1.0 & 0.2 & 1.2 \\
\hline \multicolumn{11}{|l|}{ Micronutrients } \\
\hline Iodine+DOX & 20 & 100 & 1.0 & 0.2 & 1.2 & 20 & 100 & 1.0 & 0.2 & 1.2 \\
\hline Vitamin D3+DOX & $0.001^{*}$ & $500^{*}$ & NS & NS & NA & $0.001^{*}$ & $500^{*}$ & NS & NS & NA \\
\hline Vitamin C+DOX & $88^{*}$ & $500^{*}$ & NS & NS & NA & $88^{*}$ & $500^{*}$ & NS & NS & NA \\
\hline
\end{tabular}

Abbreviations: $\mathrm{MBC}_{50}$-minimal concentration causing at least $50 \%$ of killing, NS-not susceptible/not satisfying $\mathrm{MBC}_{50}$ requirement at the maximal tested concentration, NA-not applicable, FBC-fractional bactericidal concentration, FBCI-fractional bactericidal concentration index, PH-phytochemical/micronutrient, DOX-doxycycline, RA-rosmarinic acid, *-maximal tested concentration.

MBCs of single dose of: doxycycline (NS), baicalein $(350 \mu \mathrm{g} / \mathrm{ml})$, luteolin $(200 \mu \mathrm{g} / \mathrm{ml}$ for B. burgdorferi, NS for B. garinii), monolaurin (300 $\mu \mathrm{g} / \mathrm{ml}), 10-\mathrm{HAD}(500 \mu \mathrm{g} / \mathrm{ml})$, rosmarinic acid (NS), iodine $(20 \mu \mathrm{g} / \mathrm{ml})$, vitamin D3 (NS), vitamin C (NS) [47].
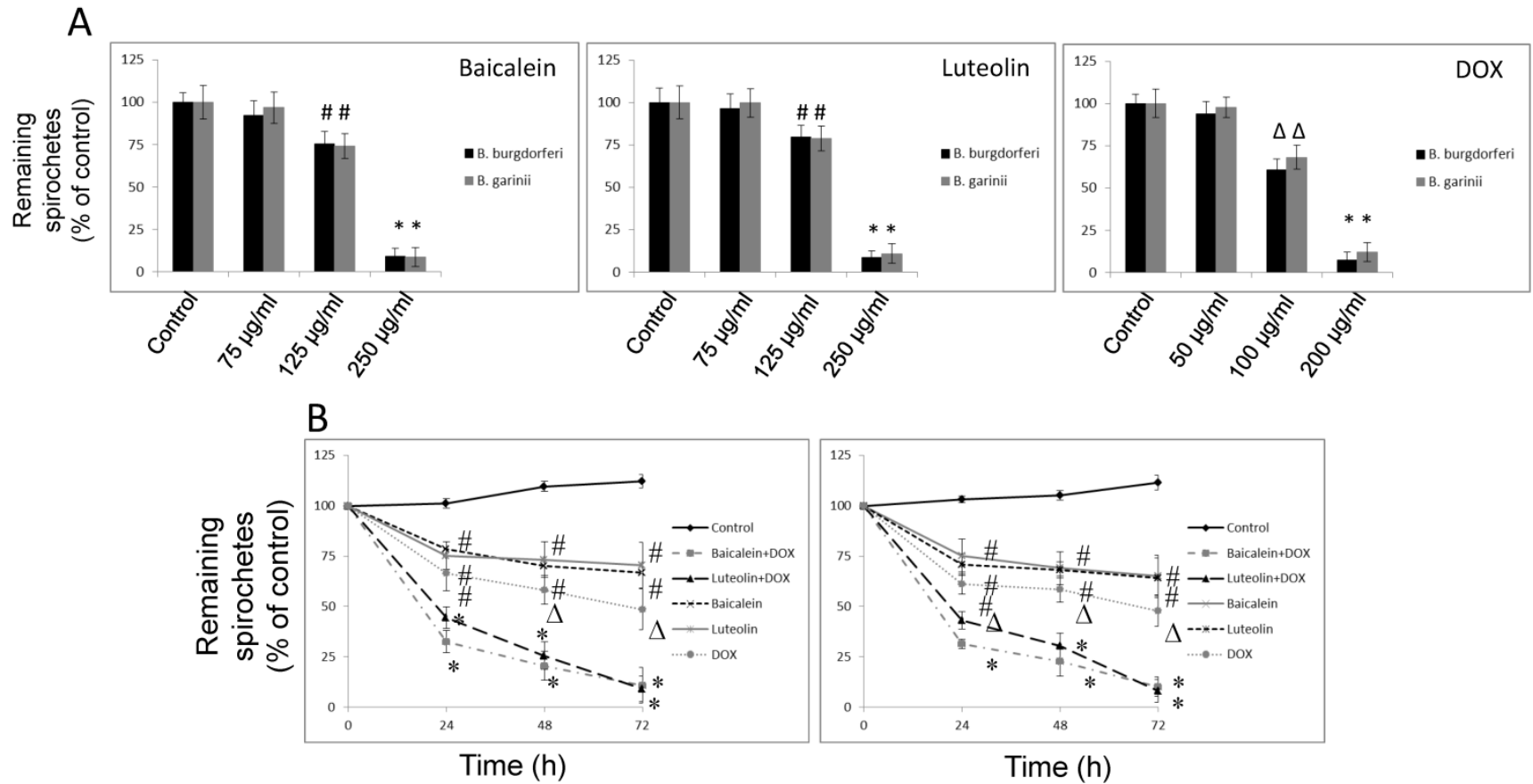

Figure 1. (A) Dose-dependent anti-bacterial effect on spirochetes of B. burgdorferi B31 strain and B. garinii CIP103362 strain after $72 \mathrm{~h}$ of treatment with tested compounds: baicalein, luteolin, and doxycycline (DOX), \# $\mathrm{p} \leq 0.05, * \leq 0.001$. (B) Kinetic evaluation of bactericidal effect of doxycycline in combination with phytochemicals on spirochetes of B. burgdorferi B31 strain and B. garinii CIP103362 strain monitored up to $72 \mathrm{~h}$; tested compounds: $125 \mu \mathrm{g} / \mathrm{ml}$ baicalein, $125 \mu \mathrm{g} / \mathrm{ml}$ luteolin, $100 \mu \mathrm{g} / \mathrm{ml}$ doxycycline (DOX) for B. burgdorferi or $125 \mu \mathrm{g} / \mathrm{ml}$ doxycycline for B. garinii, control (0.2-0.4\% v/v ethanol); \# $\leq \leq 0.05, \Delta \mathrm{p} \leq 0.01, * \leq 0.001$. 


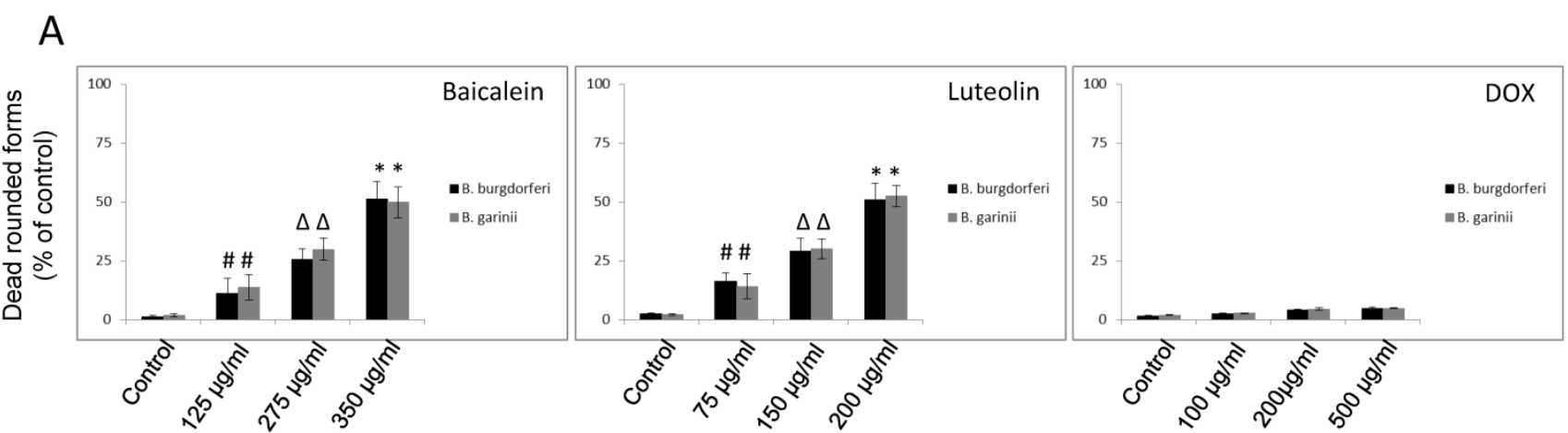

\section{B}

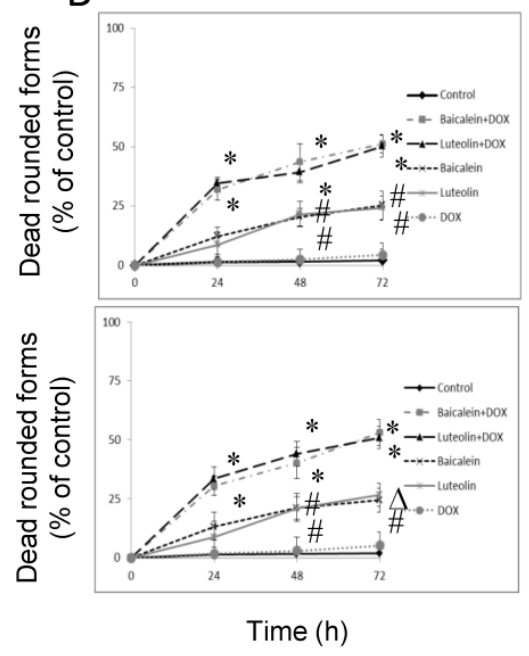

C
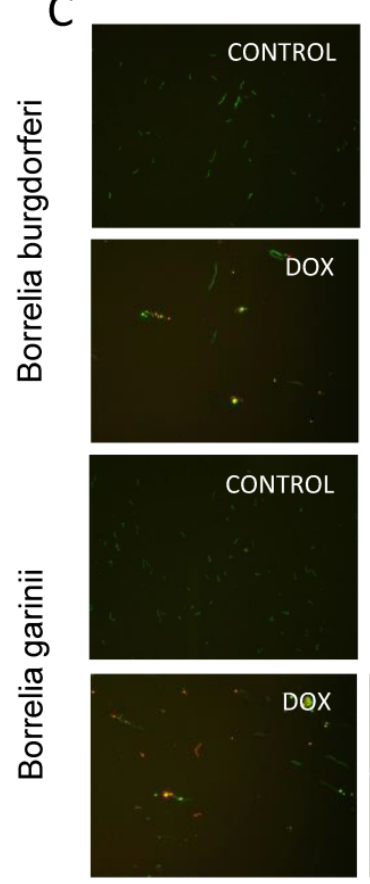
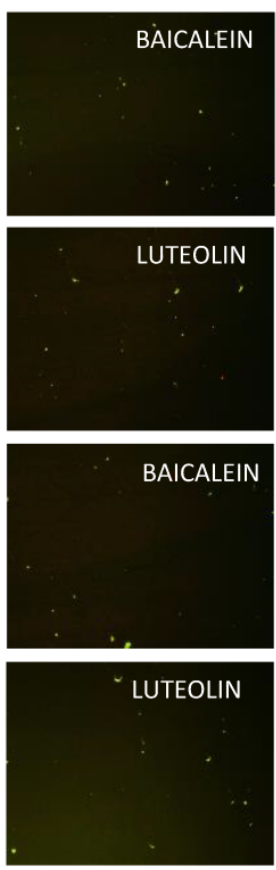

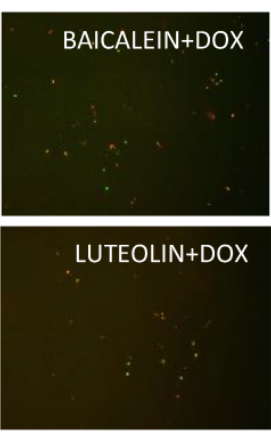

BAICALEIN+DOX

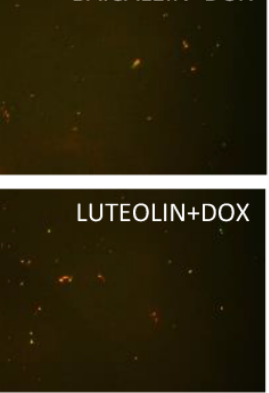

Figure 2. (A) Dose-dependent anti-bacterial effect on rounded forms of B. burgdorferi B31 strain and B. garinii CIP103362 strain after $72 \mathrm{~h}$ of treatment with tested compounds: baicalein, luteolin, and doxycycline (DOX), \# $p \leq 0.05, \Delta p \leq 0.01, * \leq 0.001$. (B) Kinetic evaluation of bactericidal effect of doxycycline in combination with phytochemicals on rounded forms of $B$. burgdorferi B31 strain and B. garinii CIP103362 strain monitored up to $72 \mathrm{~h}$; tested compounds: $275 \mu \mathrm{g} / \mathrm{ml}$ baicalein, 150 $\mu \mathrm{g} / \mathrm{ml}$ luteolin, $100 \mu \mathrm{g} / \mathrm{ml}$ doxycycline (DOX), control $(0.2-0.4 \% \mathrm{v} / \mathrm{v}$ ethanol); \# $\mathrm{p} \leq 0.05, \Delta \mathrm{p} \leq 0.01$, * $\leq 0.001$. (C) Representative images of $B$. burgdorferi B31 strain and B. garinii CIP103362 strain SYTO ${ }^{\otimes 9}$ (green) and propidium iodine (red) taken under $200 \times$ magnification; tested compounds: $275 \mu g / \mathrm{ml}$ baicalein, $150 \mu \mathrm{g} / \mathrm{ml}$ luteolin, $100 \mu \mathrm{g} / \mathrm{ml}$ doxycycline (DOX), control (0.2-0.4\% v/v ethanol).

Reciprocal cooperation between doxycycline and tested phytochemicals against biofilm of Borrelia sp. The combinations of doxycycline with test phytochemicals and micronutrients against biofilm formed by test microorganisms with the $\mathrm{EC}_{50} \mathrm{~S}$, FECs, and FECIs are presented in Table 3. In our previous study we observed that several of these compounds had anti-biofilm effects that satisfied the $\mathrm{EC}_{50}$ requirement. These were baicalein, luteolin, monolaurin, 10-HAD, and iodine for B. burgdorferi, as well as baicalein and monolaurin for B. garinii. The other tested agents such as rosmarinic acid, vitamin D3, and vitamin C did not display such effect [47]. The results obtained from this study show that neither synergy nor antagonism was observed. The additive anti-biofilm effect was achieved when doxycycline was co-administrated with baicalein, luteolin, and iodine, respectively (valid for both tested Borrelia sp.), significantly reducing established biofilms of test microorganisms by $\sim 50-60 \%$, and satisfying the $\mathrm{EC}_{50}$ requirement (Figure $3 \mathrm{~A}$ and $\mathrm{B}$ ). Combinations of doxycycline with flavones were able to enhance eradication of biofilm up to $50 \%$ at their lower effective concentrations which decreased from 750 $\mu \mathrm{g} / \mathrm{ml}$ to $500 \mu \mathrm{g} / \mathrm{ml}$ for baicalein, and from 350 $\mu \mathrm{g} / \mathrm{ml}$ to $175 \mu \mathrm{g} / \mathrm{ml}$ for luteolin, and from $40 \mu \mathrm{g} / \mathrm{ml}$ to $20 \mu \mathrm{g} / \mathrm{ml}$ for iodine. At the same time doxycycline concentration could also be decreased from $250 \mu \mathrm{g} / \mathrm{ml}$ to $125 \mu \mathrm{g} / \mathrm{ml}$. Their FECs and FECIs corresponded to each other for both tested species of Borrelia. Indifference (no interaction) was seen for doxycycline combined with fatty acids such as monolaurin and 
10-HAD. EC $\mathrm{E}_{50}$ mark was achieved at their values identical to these of their single dose such as 375 $\mu \mathrm{g} / \mathrm{ml}$ for monolaurin, $800 \mu \mathrm{g} / \mathrm{ml}$ for $10-H A D$, and at the same time allowing for reducing doxycycline concentration from $250 \mu \mathrm{g} / \mathrm{ml}$ to $125 \mu \mathrm{g} / \mathrm{ml}$. The combinations with the rest of the tested agents did not achieve $\mathrm{EC}_{50}$ mark, which did not allow performing correct calculations. None of the agents tested alone or in combinations could eradicate biofilms of both studied Borrelia sp. in 90-99\%, even when their maximal tested concentration was applied. This is a very rigorous requirement for any antibiotic, including doxycycline, for which anti-biofilm efficacy was shown to be $\sim 30-40 \%$ at $250 \mu \mathrm{g} / \mathrm{ml}[2,47]$.

Table 3. Antibacterial reciprocal cooperation of doxycycline with phytochemicals and micronutrients against biofilm of Borrelia burgdorferi and Borrelia garinii.

\begin{tabular}{|c|c|c|c|c|c|c|c|c|c|c|}
\hline \multirow[t]{3}{*}{ Tested combination } & \multicolumn{5}{|c|}{ Borrelia burgdorferi } & \multicolumn{5}{|c|}{ Borrelia garinii } \\
\hline & \multicolumn{2}{|c|}{$\mathrm{EC}_{50}$ in combination } & \multicolumn{2}{|c|}{ FEC } & \multirow[t]{2}{*}{ FECI } & \multicolumn{2}{|c|}{$\mathrm{EC}_{50}$ in combination } & \multicolumn{2}{|c|}{ FEC } & \multirow[t]{2}{*}{ FECI } \\
\hline & $\begin{array}{l}\mathrm{PH} \\
(\mu \mathrm{g} / \mathrm{ml})\end{array}$ & $\begin{array}{l}\text { DOX } \\
(\mu \mathrm{g} / \mathrm{ml})\end{array}$ & $\mathrm{PH}$ & DOX & & $\begin{array}{l}\text { PH } \\
(\mu \mathrm{g} / \mathrm{ml})\end{array}$ & $\begin{array}{l}\text { DOX } \\
(\mu \mathrm{g} / \mathrm{ml})\end{array}$ & $\mathrm{PH}$ & DOX & \\
\hline \multicolumn{11}{|l|}{ Polyphenols } \\
\hline Baicalein+DOX & 375 & 125 & 0.5 & 0.5 & 1.0 & 375 & 125 & 0.5 & 0.5 & 1.0 \\
\hline Luteolin+DOX & 200 & 125 & 0.5 & 0.5 & 1.0 & 200 & 125 & 0.5 & 0.5 & 1.0 \\
\hline RA+DOX & $500^{*}$ & $500^{*}$ & NS & NS & NA & $500^{*}$ & $500^{*}$ & NS & NS & NA \\
\hline \multicolumn{11}{|l|}{ Fatty acids } \\
\hline Monolaurin+Dx & 750 & 125 & 1.0 & 0.5 & 1.5 & 750 & 125 & 1.0 & 0.5 & 1.5 \\
\hline 10-HAD+DOX & 800 & 125 & 1.0 & 0.5 & 1.5 & 800 & 125 & 1.0 & 0.5 & 1.5 \\
\hline \multicolumn{11}{|l|}{ Micronutrients } \\
\hline Iodine+DOX & 20 & 125 & 0.5 & 0.5 & 1.0 & 20 & 125 & 0.5 & 0.5 & 2.0 \\
\hline Vitamin D3+DOX & $0.001^{*}$ & $500^{*}$ & NS & NS & NA & $0.001^{*}$ & $500^{*}$ & NS & NS & NA \\
\hline Vitamin C+DOX & $88^{*}$ & $500^{*}$ & NS & NS & NA & $88^{*}$ & $500^{*}$ & NS & NS & NA \\
\hline
\end{tabular}

Abbreviations: EC50-effective concentration causing at least $50 \%$ of eradication, NS-not susceptible/not satisfying EC 50 requirement at the maximal tested concentration, NA-not applicable, FEC-fractional eradication concentration, FECI-fractional eradication concentration index, $\mathrm{PH}$-phytochemical/micronutrient, DOX-doxycycline, RA-rosmarinic acid, *-maximal tested concentration.

$\mathrm{EC}_{50}$ S of single dose of: doxycycline (NS), baicalein $(750 \mu \mathrm{g} / \mathrm{ml})$, luteolin $(350 \mu \mathrm{g} / \mathrm{ml}$ for B. burgdorferi, NS for B. garinii), monolaurin $(750 \mu \mathrm{g} / \mathrm{ml}), 10-\mathrm{HAD}(800 \mu \mathrm{g} / \mathrm{ml})$, rosmarinic acid (NS), iodine $(40 \mu \mathrm{g} / \mathrm{ml})$, vitamin D3 (NS), vitamin C (NS) [47].

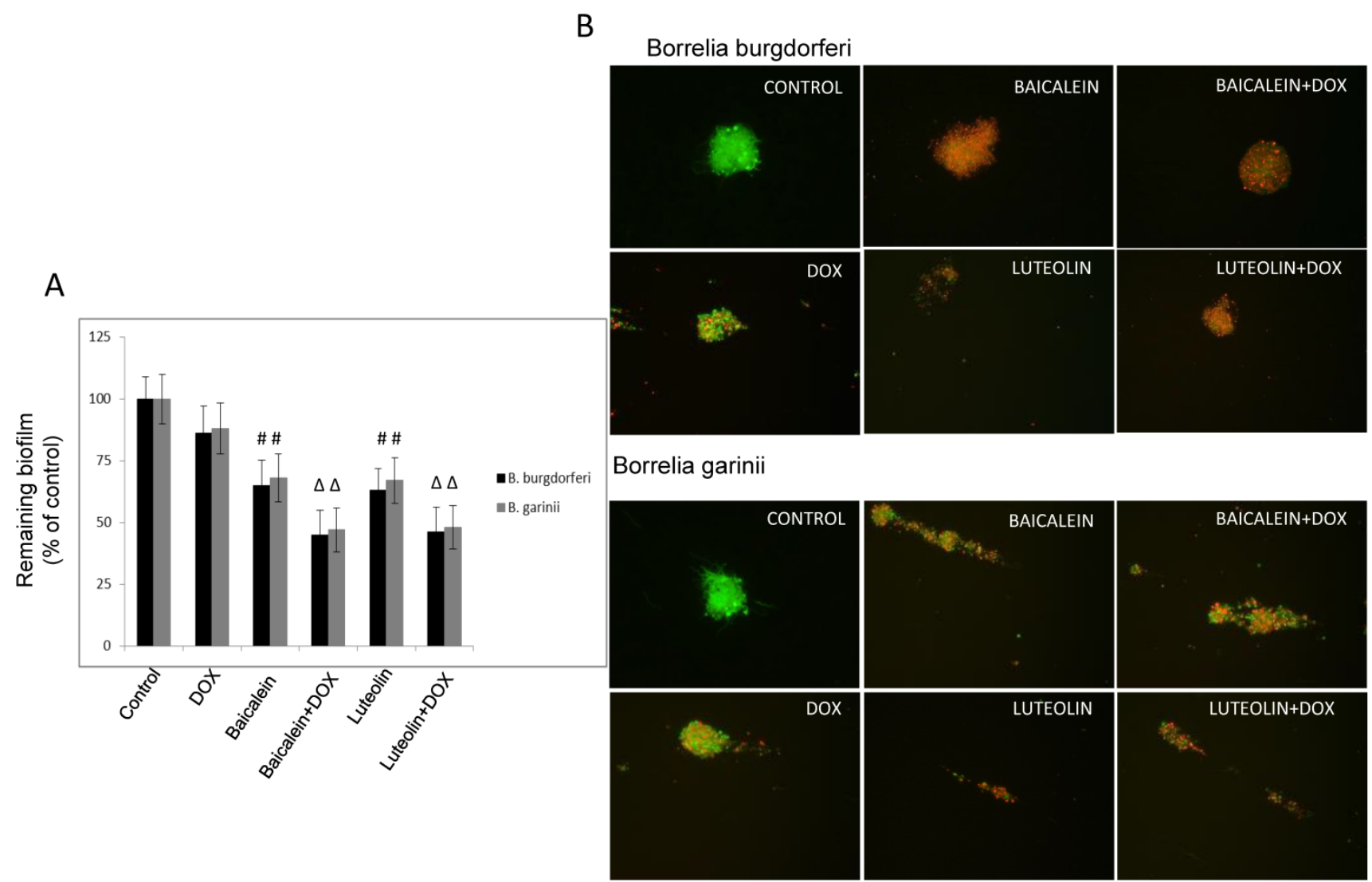

Figure 3. (A) Evaluation of remaining biofilm of $B$. burgdorferi $B 31$ strain and $B$. garinii CIP103362 strain after 72 treatment with tested compounds determined by crystal violet staining; tested compounds: $375 \mu \mathrm{g} / \mathrm{ml}$ baicalein, $200 \mu \mathrm{g} / \mathrm{ml}$ luteolin, $125 \mu \mathrm{g} / \mathrm{ml}$ doxycycline (DOX), control (0.2-0.4\% v/v ethanol). (B) Representative images of B. burgdorferi B31 strain and B. garinii CIP103362 strain biofilm stained with SYTO ${ }^{\circledR 9}$ (green) and propidium iodine (red) taken under $400 \times$ magnification; tested compounds: $375 \mu \mathrm{g} / \mathrm{ml}$ baicalein, $200 \mu \mathrm{g} / \mathrm{ml}$ luteolin, $125 \mu \mathrm{g} / \mathrm{ml}$ doxycycline (DOX), control $(0.2-0.4 \% \mathrm{v} / \mathrm{v}$ ethanol). 


\section{Discussion}

Borrelia $s p$. is the cause of Lyme disease in mammals. The emergence of the relapse of symptoms of this disease has been noticed [7, 19, 37, 55]. The challenge in treating these bacteria has been complicated by several pathophysiological factors, including their ability to remain latent for decades [5, 56-58]. The challenge is further exacerbated by findings indicating that Borrelia biofilm may harbor a heterogeneous population of spirochetes and rounded forms with distinct genetic and protein profiles [59-61]. In addition, the role of an antibiotic efflux gene needs to be explored [22].

Improved prospects in targeting Borrelia sp. may result from applications of agents that cooperate in eliminating spirochetes as well as their dormant forms. Therefore, it is important to investigate the interaction of such agents with the most common clinically used antibiotics against LD, like doxycycline.

Our previous study indicated that phytochemicals may provide a new reservoir of active antimicrobial agents, and serve as a resource for the development of novel anti-borreliae approaches [47]. That study showed that the most promising compounds effective against spirochete and/or latent forms of Borrelia sp. were flavones such as baicalein and luteolin, fatty acids including monolaurin and 10-HAD, and iodine. Also vitamins D3 and C, and rosmarinic acid demonstrated bacteriostatic effects. Doxycycline was effective against the spirochete form and had a moderate effect against biofilm. However, the exposure of Borrelia $s p$. to doxycycline concentration even 10-20 times higher than its MIC value did not show efficacy towards rounded forms $[2,47]$. That might lead to a subsequent loss of doxycycline efficacy in vitro and in vivo when applied long-term. Taking all these aspects into consideration, we were interested in evaluating the reciprocal interactions of these phytochemicals and micronutrients with doxycycline against active and latent forms of Borrelia sp.

In the present study, we tested eight combinations of phytochemicals with doxycycline against all morphological forms of Borrelia $s p$. Although the synergy was not observed, the antagonism was not present either. Additive effects were confined to a small number of combinations against latent forms (doxycycline with baicalein or luteolin), while against spirochetes these activities were noticeable with more combinations, such as doxycycline with baicalein, luteolin, iodine, rosmarinic acid, and vitamin D3 or vitamin C. Indifference was demonstrated for a combination of doxycycline with fatty acids such as monolaurin and 10-HAD. Time-dependent bactericidal effects against spirochetes and latent rounded forms of Borrelia burgdorferi and Borrelia garinii were observed when doxycycline was combined with the flavones baicalein and luteolin, respectively, at concentrations fulfilling the $0.5<\mathrm{FBCI}<1.0$ requirement. Interestingly, the addition of iodine did not improve doxycycline's efficacy towards rounded forms, but demonstrated additive effects against spirochete and biofilm forms of both tested Borrelia sp. Whether similar in vitro effects can be replicated in vivo, merits further studies.

There are only a few published reports about reciprocal interactions between doxycycline and other antibiotics, and none of them used Borrelia sp. as a subject matter. As such, Bruhn, et al., reported synergism of the precursor spectinomycin with antibiotics. This observation prompted them to examine whether spectinamides sensitize Mycobacterium tuberculosis to antibiotics not traditionally used in the treatment of tuberculosis. They noticed synergy with clarithromycin, doxycycline and clindamycin against clinical isolates. Further in vivo study of the efficacy of these combinations documented additional bacterial killing effect in a mouse model of acute tuberculosis infection, but not in a chronic infection model [62]. In the study of Gonzalo, et al., amikacin in combination with doxycycline tested against clinical strains of Mycobacterium tuberculosis showed a synergistic effect in 18 of the 29 strains, and indifference in 11 strains [63]. Supporting data obtained by Rodríguez-Hernández, et al., suggest that addition of amikacin does not improve the results obtained by imipenem monotherapy, but adding doxycycline to amikacin is an alternative to imipenem in the therapy of Acinetobacter baumannii pneumonia [64].

Even fewer studies have investigated the interactions of doxycycline with phytochemicals and none with micronutrients. Among these, research by Valcourt, et al., showed synergy between doxycycline and essential oils (EOs) such as carvacrol (oregano oil), eugenol (clove oil) and cinnamaldehyde (cinnamon oil) against Gram-negative strains of Acinetobacter baumannii, Klebsiella pneumoniae, Escherichia coli, and Pseudomonas aeruginosa. No growth inhibiting interactions were found between EOs and doxycycline, however, synergistic bactericidal effects were observed, supported by the results visualizing the holes-type destructive changes in the bacterial membrane with the leakage of cellular contents [65]. There is one report demonstrating synergy of baicalein with tetracycline and beta-lactams against methicillin-resistant Staphylococcus aureus [66]. In addition, synergistic 
effect was demonstrated when luteolin was co-administrated with ceftazidime against Streptococcus pyogenes that concluded that luteolin has high potential to be developed as an adjunct to ceftazidime for the treatment of beta-lactamase-producing bacteria and Streptococcus pyogenes infections [67]. Moreover, Isenberg, et al., found that half-strength $(5 \%)$ povidone-iodine solution significantly reduced bacterial flora of the conjunctiva. Later, they compared this concentration of povidone-iodine on the conjunctiva with a prophylactic antibiotic (Neosporin ophthalmic solution) in 35 patients undergoing ocular surgery. The results showed that the antibiotic and povidone-iodine solutions, used individually, caused a similar and substantial decrease in the number of colonies (biofilm) and species of bacteria cultured. However, when both drugs were used together the decrease was even more striking, making $83 \%$ of the conjunctivae sterile. Thus, their recommendation was to use a broad-spectrum topical antibiotic with the half-strength povidone-iodine solution as a part of the preoperative preparation [68].

Synergistic or additive interactions are not universal which makes it difficult to compare and generalize the results. In addition, the use of different testing methods further complicates interpretation of the results. We find it promising that our results obtained with Borrelia sp. corroborate with the findings of other research groups. It is important to note that while bactericidal concentrations of doxycycline may induce persistent phenotypic changes, combining it with selected phytochemicals or micronutrients may not only allow for reducing its concentration to more "safe" values, but also expand the spectrum of bacterial forms affected and perhaps offer additional benefits such as anti-inflammatory properties.

In summary, this study documents in vitro efficacy of doxycycline co-administrated with several phytochemicals and micronutrients against active and latent persistent forms of Borrelia burgdorferi sensu stricto and Borrelia garinii. These findings indicate an additive effect of doxycycline co-administrated with flavones like baicalein or luteolin against all morphological forms of these species in vitro. Therefore, combinations of these phytochemicals with an antibiotic present a promising alternative towards combating Borrelia $s p$. The study provides additional support for phytochemicals as valuable adjuvants in antimicrobial chemotherapy, although further in vivo and human studies are warranted to draw a final conclusion.

\section{Acknowledgment}

The authors thank Ms. Cathy Flowers and Waldemar Sumera, MS, for valuable input during preparation of the manuscript. Funds were provided by the non-profit Dr. Rath Health Foundation, a separate entity from the Dr. Rath Research Institute BV. All authors are not hired by the Dr. Rath Health Foundation and the funders had no role in the study design, performance, data collection and analysis, decision to publish, or preparation of the manuscript.

\section{Conflict of Interest}

No conflict of interest to declare.

\section{References}

1. Embers ME, Barthold SW, Borda JT, Bowers L, Doyle L, Hodzic E, et al. Persistence of Borrelia burgdorferi in rhesus macaques following antibiotic treatment of disseminated infection. PloS one. 2012; 7: e29914.

2. Sapi E, Kaur N, Anyanwu S, Luecke DF, Datar A, Patel S, et al. Evaluation of in-vitro antibiotic susceptibility of different morphological forms of Borrelia burgdorferi. Infection and drug resistance. 2011; 4: 97-113.

3. Hodzic E, Imai D, Feng S, Barthold SW. Resurgence of persisting non-cultivable Borrelia burgdorferi following antibiotic treatment in mice. PloS one. 2014; 9: e86907.

4. Stanek G, Wormser GP, Gray J, Strle F. Lyme borreliosis. Lancet. 2012; 379: 461-73.

5. Hodzic E, Feng S, Holden K, Freet KJ, Barthold SW. Persistence of Borrelia burgdorferi following antibiotic treatment in mice. Antimicrobial agents and chemotherapy. 2008; 52: 1728-36.

6. Stricker RB, Johnson L. Borrelia burgdorferi aggrecanase activity: more evidence for persistent infection in Lyme disease. Frontiers in cellular and infection microbiology. 2013; 3: 40.

7. Barthold SW, Hodzic E, Imai DM, Feng S, Yang X, Luft BJ. Ineffectiveness of tigecycline against persistent Borrelia burgdorferi. Antimicrobial agents and chemotherapy. 2010; 54: 643-51.

8. Anderson JF, Magnarelli LA, Burgdorfer W, Barbour AG. Spirochetes in Ixodes dammini and mammals from Connecticut. The American journal of tropical medicine and hygiene. 1983; 32: 818-24.

9. Burgdorfer W, Barbour AG, Hayes SF, Benach JL, Grunwaldt E, Davis JP. Lyme disease-a tick-borne spirochetosis? Science. 1982; 216: 1317-9.

10. Johnson L, Wilcox S, Mankoff J, Stricker RB. Severity of chronic Lyme disease compared to other chronic conditions: a quality of life survey. PeerJ. 2014; 2: e322.

11. Dryden MW, Hodgkins E. Vector-borne diseases in pets: the stealth health threat. Compendium. 2010; 32: E1-4.

12. Lovrich SD, Callister SM, Lim LC, DuChateau BK, Schell RF. Seroprotective groups of Lyme borreliosis spirochetes from North America and Europe. The Journal of infectious diseases. 1994; 170: 115-21.

13. Miller KA, Motaleb MA, Liu J, Hu B, Caimano MJ, Miller MR, et al. Initial characterization of the FlgE hook high molecular weight complex of Borrelia burgdorferi. PloS one. 2014; 9: e98338.

14. Zhao X, Norris SJ, Liu J. Molecular architecture of the bacterial flagellar motor in cells. Biochemistry. 2014; 53: 4323-33.

15. Wu J, Weening EH, Faske JB, Hook M, Skare JT. Invasion of eukaryotic cells by Borrelia burgdorferi requires beta(1) integrins and Src kinase activity. Infection and immunity. 2011; 79: 1338-48.

16. Coleman JL, Sellati TJ, Testa JE, Kew RR, Furie MB, Benach JL. Borrelia burgdorferi binds plasminogen, resulting in enhanced penetration of endothelial monolayers. Infection and immunity. 1995; 63: 2478-84.

17. Gruntar I, Malovrh T, Murgia R, Cinco M. Conversion of Borrelia garinii cystic forms to motile spirochetes in vivo. APMIS : acta pathologica, microbiologica, et immunologica Scandinavica. 2001; 109: 383-8.

18. Brorson $\mathrm{O}$, Brorson $\mathrm{SH}$. In vitro conversion of Borrelia burgdorferi to cystic forms in spinal fluid, and transformation to mobile spirochetes by incubation in BSK-H medium. Infection. 1998; 26: 144-50.

19. Brorson $\mathrm{O}$, Brorson $\mathrm{SH}$, Scythes J, MacAllister J, Wier A, Margulis L. Destruction of spirochete Borrelia burgdorferi round-body propagules (RBs) by the antibiotic tigecycline. Proceedings of the National Academy of Sciences of the United States of America. 2009; 106: 18656-61.

20. Krause PJ, Foley DT, Burke GS, Christianson D, Closter L, Spielman A, et al. Reinfection and relapse in early Lyme disease. The American journal of tropical medicine and hygiene. 2006; 75: 1090-4.

21. Donta ST. Late and chronic Lyme disease. The Medical clinics of North America. 2002; 86: 341-9, vii. 
22. Fraser CM, Casjens S, Huang WM, Sutton GG, Clayton R, Lathigra R, et al. Genomic sequence of a Lyme disease spirochaete, Borrelia burgdorferi. Nature. 1997; 390: 580-6.

23. Stricker RB, Johnson L. Lyme disease: call for a "Manhattan Project" to combat the epidemic. PLoS pathogens. 2014; 10: e1003796.

24. Meek JI, Roberts CL, Smith EV, Jr., Cartter ML. Underreporting of Lyme disease by Connecticut physicians, 1992. Journal of public health management and practice : JPHMP. 1996; 2: 61-5.

25. Shapiro ED. Lyme disease. The New England journal of medicine. 2014; 371: 684.

26. Cameron DJ, Johnson LB, Maloney EL. Evidence assessments and guideline recommendations in Lyme disease: the clinical management of known tick bites, erythema migrans rashes and persistent disease. Expert review of anti-infective therapy. 2014; 12: 1103-35.

27. Nadelman RB, Nowakowski J, Fish D, Falco RC, Freeman K, McKenna D, et al. Prophylaxis with single-dose doxycycline for the prevention of Lyme disease after an Ixodes scapularis tick bite. The New England journal of medicine. 2001; 345: 79-84

28. Wormser GP, Dattwyler RJ, Shapiro ED, Halperin JJ, Steere AC, Klempner MS, et al. The clinical assessment, treatment, and prevention of lyme disease, human granulocytic anaplasmosis, and babesiosis: clinical practice guidelines by the Infectious Diseases Society of America. Clinical infectious diseases : an official publication of the Infectious Diseases Society of America. 2006; 43: 1089-134.

29. Mygland A, Ljostad U, Fingerle V, Rupprecht T, Schmutzhard E, Steiner I, et al. EFNS guidelines on the diagnosis and management of European Lyme neuroborreliosis. European journal of neurology. 2010; 17: 8-16, e1-4.

30. Li JJ, Corey EJ. Drug discovery. Practices, processes, and perspectives. Hoboken, NJ: John Wiley \& Sons, Inc. 2013.

31. Nelson ML, Levy SB. The history of the tetracyclines. Ann NY Acad Sci. 2011; 1241:17-32.

32. [Internet] WOHO. Geneva, Switzerland. WHO Model List of Essential Medicines. Revised April 2015. http://www.who.int/medicines/ publications/essentialmedicines/en/

33. [Internet] The American Society of Health-System Pharmacists. Doxycycline calcium. http:// www.drugs.com.

34. Mylonas I. Antibiotic chemotherapy during pregnancy and lactation period: aspects for consideration. Archives of gynecology and obstetrics. 2011; 283: 7-18.

35. Delong AK, Blossom B, Maloney EL, Phillips SE. Antibiotic retreatment of Lyme disease in patients with persistent symptoms: a biostatistical review of randomized, placebo-controlled, clinical trials. Contemporary clinical trials. 2012; 33: 1132-42.

36. Baradaran-Dilmaghani R, Stanek G. In vitro susceptibility of thirty Borrelia strains from various sources against eight antimicrobial chemotherapeutics. Infection. 1996; 24: 60-3.

37. Klempner MS, Hu LT, Evans J, Schmid CH, Johnson GM, Trevino RP, et al. Two controlled trials of antibiotic treatment in patients with persistent symptoms and a history of Lyme disease. The New England journal of medicine. 2001; 345: 85-92.

38. Oksi J, Marjamaki M, Nikoskelainen J, Viljanen MK. Borrelia burgdorferi detected by culture and PCR in clinical relapse of disseminated Lyme borreliosis. Annals of medicine. 1999; 31: 225-32.

39. Straubinger RK, Summers BA, Chang YF, Appel MJ. Persistence of Borrelia burgdorferi in experimentally infected dogs after antibiotic treatment. Journal of clinical microbiology. 1997; 35: 111-6.

40. Straubinger RK. PCR-Based quantification of Borrelia burgdorferi organisms in canine tissues over a 500-Day postinfection period. Journal of clinical microbiology. 2000; 38: 2191-9.

41. Morrison KC, Hergenrother PJ. Natural products as starting points for the synthesis of complex and diverse compounds. Natural product reports. 2014; 31: 6-14.

42. Takeuchi H, Trang VT, Morimoto N, et al. Natural products and food components with anti-Helicobacter pylori activities. World J Gastroenterol. 2014; 20: 8971-8

43. Zhang L, Ravipati AS, Koyyalamudi SR, et al. Anti-fungal and anti-bacterial activities of ethanol extracts of selected traditional Chinese medicinal herbs. Asian Pac J Trop Med. 2013; 6: 673-81.

44. Brorson O, Brorson SH. Grapefruit seed extract is a powerful in vitro agent against motile and cystic forms of Borrelia burgdorferi sensu lato. Infection. 2007; 35: 206-8.

45. Liebold T, Straubinger RK, Rauwald HW. Growth inhibiting activity of lipophilic extracts from Dipsacus sylvestris Huds. roots against Borrelia burgdorferi s. s. in vitro. Die Pharmazie. 2011; 66: 628-30.

46. Theophilus PA, Victoria MJ, Socarras KM, Filush KR, Gupta K, Luecke DF, et al. Effectiveness of Stevia Rebaudiana Whole Leaf Extract Against the Various Morphological Forms of Borrelia Burgdorferi in Vitro. European journal of microbiology \& immunology. 2015; 5: 268-80.

47. Goc A, Niedzwiecki A, Rath $M$. In vitro evaluation of antibacterial activity of phytochemicals and micronutrients against Borrelia burgdorferi and Borrelia garinii. Journal of applied microbiology. 2015.

48. Jeong N, Kim JY, Park SC, Lee JK, Gopal R, Yoo S, et al. Antibiotic and synergistic effect of Leu-Lys rich peptide against antibiotic resistant microorganisms isolated from patients with cholelithiasis. Biochemical and biophysical research communications. 2010; 399: 581-6.
49. Dawis MA, Isenberg HD, France KA, Jenkins SG. In vitro activity of gatifloxacin alone and in combination with cefepime, meropenem, piperacillin and gentamicin against multidrug-resistant organisms. The Journal of antimicrobial chemotherapy. 2003; 51: 1203-11.

50. Gopal R, Kim YG, Lee JH, Lee SK, Chae JD, Son BK, et al. Synergistic effects and antibiofilm properties of chimeric peptides against multidrug-resistant Acinetobacter baumannii strains. Antimicrobial agents and chemotherapy. 2014; 58: 1622-9.

51. Zasloff M. Magainins, a class of antimicrobial peptides from Xenopus skin: isolation, characterization of two active forms, and partial cDNA sequence of a precursor. Proceedings of the National Academy of Sciences of the United States of America. 1987; 84: 5449-53.

52. Privett BJ, Deupree SM, Backlund CJ, Rao KS, Johnson CB, Coneski PN, et al. Synergy of nitric oxide and silver sulfadiazine against gram-negative, gram-positive, and antibiotic-resistant pathogens. Molecular pharmaceutics. 2010; 7: 2289-96

53. Elion GB, Singer S, Hitchings GH. Antagonists of nucleic acid derivatives. VIII. Synergism in combinations of biochemically related antimetabolites. The Journal of biological chemistry. 1954; 208: 477-88.

54. Dever LL, Jorgensen JH, Barbour AG. In vitro antimicrobial susceptibility testing of Borrelia burgdorferi: a microdilution MIC method and time-kill studies. Journal of clinical microbiology. 1992; 30: 2692-7.

55. Chang YF, Ku YW, Chang CF, Chang CD, McDonough SP, Divers T, et al. Antibiotic treatment of experimentally Borrelia burgdorferi-infected ponies. Veterinary microbiology. 2005; 107: 285-94.

56. Girschick HJ, Huppertz HI, Russmann H, Krenn V, Karch H. Intracellular persistence of Borrelia burgdorferi in human synovial cells. Rheumatology international. 1996; 16: 125-32.

57. Goodman JL, Jurkovich P, Kodner C, Johnson RC. Persistent cardiac and urinary tract infections with Borrelia burgdorferi in experimentally infected Syrian hamsters. Journal of clinical microbiology. 1991; 29: 894-6.

58. James FM, Engiles JB, Beech J. Meningitis, cranial neuritis, and radiculoneuritis associated with Borrelia burgdorferi infection in a horse. Journal of the American Veterinary Medical Association. 2010; 237: 1180-5.

59. Alban PS, Johnson PW, Nelson DR. Serum-starvation-induced changes in protein synthesis and morphology of Borrelia burgdorferi. Microbiology. 2000; 146 ( Pt 1): 119-27.

60. Sapi E, Bastian SL, Mpoy CM, Scott S, Rattelle A, Pabbati N, et al. Characterization of biofilm formation by Borrelia burgdorferi in vitro. PloS one. 2012; 7: e48277.

61. Timmaraju VA, Theophilus PA, Balasubramanian K, Shakih S, Luecke DF, Sapi E. Biofilm formation by Borrelia burgdorferi sensu lato. FEMS microbiology letters. 2015; 362: fnv120.

62. Bruhn DF, Scherman MS, Liu J, Scherbakov D, Meibohm B, Bottger EC, et al. In vitro and in vivo Evaluation of Synergism between Anti-Tubercular Spectinamides and Non-Classical Tuberculosis Antibiotics. Scientific reports. 2015; 5: 13985

63. Gonzalo X, Casali N, Broda A, Pardieu C, Drobniewski F Combination of amikacin and doxycycline against multidrug-resistant and extensively drug-resistant tuberculosis. International journal of antimicrobial agents. 2015; 45: 406-12.

64. Rodriguez-Hernandez MJ, Pachon J, Pichardo C, Cuberos L, Ibanez-Martinez J, Garcia-Curiel A, et al. Imipenem, doxycycline and amikacin in monotherapy and in combination in Acinetobacter baumannii experimental pneumonia. The Journal of antimicrobial chemotherapy. 2000; 45: 493-501.

65. Valcourt C, Saulnier P, Umerska A, Zanelli MP, Montagu A, Rossines E, et al. Synergistic interactions between doxycycline and terpenic components of essential oils encapsulated within lipid nanocapsules against gram negative bacteria. International journal of pharmaceutics. 2015; 498: 23-31.

66. Fujita M, Shiota S, Kuroda T, Hatano T, Yoshida T, Mizushima T, et al. Remarkable synergies between baicalein and tetracycline, and baicalein and beta-lactams against methicillin-resistant Staphylococcus aureus. Microbiology and immunology. 2005; 49: 391-6.

67. Siriwong S, Thumanu K, Hengpratom T, Eumkeb G. Synergy and Mode of Action of Ceftazidime plus Quercetin or Luteolin on Streptococcus pyogenes. Evidence-based complementary and alternative medicine : eCAM. 2015; 2015: 759459 .

68. Isenberg SJ, Apt L, Yoshimori R, Khwarg S. Chemical preparation of the eye in ophthalmic surgery. IV. Comparison of povidone-iodine on the conjunctiva with a prophylactic antibiotic. Archives of ophthalmology. 1985; 103: 1340-2. 